"Every time you talk, laugh, cough, sneeze, you're generating particles that are coming out of your mouth that are various sizes," Low says. "Ballistic" particles more than 100 microns in diameter fall to the ground. But smaller particles ranging from 0.1 to 100 microns stay in the air from seconds to days, depending on humidity, airflow and ultraviolet light. These particles can be inhaled deeply into the respiratory tract, with smaller ones capable of reaching the tracheobronchial and alveolar tissues.

In practice, studies show the greatest risk is within one metre, Low adds. "Whether someone is infectious will vary [with] the amount of virus. There's a huge dilutional factor right away as soon as you get away from the person infected."

Surgical masks - designed to protect patients from surgeons - provide some protection against contact and inhalation transmission, but allow air in the sides and do not meet an established standard, Low explains.

N95 masks, however, do meet the test. Created to protect workers in the construction industry from breathing in particulates and widely available in hardware stores, they must meet standards set by the US National Institute for Occupational Safety and Health. They fit tightly on the face and block particles as small as 0.1 micron.

While PHAC states on its website that it does not recommend that healthy people wear masks as they go about their daily lives, Low says N95 masks have a role in protecting the public. "If you had somebody at home with influenza, wearing an N95 mask would be very appropriate."

Canada's Chief Public Health Officer, Dr. David Butler-Jones, states on PHAC's website, though, that it can be easy to get a false sense of security from wearing the mask.

Low counters: "I don't know where the false sense of security would come from." - Carolyn Brown, Ottawa, Ont. and Wayne Kondro, CMAJ

DOI:10.1503/cmaj.109-3066

\title{
Shift toward capitation in Ontario
}

Previously published at www.cmaj.ca

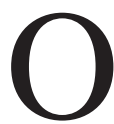
ntario family doctors are shifting from fee-for-service to capitation in ever-increasing numbers. Supporters of capitation systems say this is good news for both doctors and patients, though they warn that such systems can be complicated and difficult to operate effectively.

Canadian capitation experts say there has been little momentum in most provinces toward paying doctors annual fees for each patient - except in Ontario. About a quarter of family physicians in Ontario are paid via capitation, many abandoning fee-for-service only recently. About two-thirds of Ontario patients are enrolled in capitation systems or so-called blended systems, which retain some feefor-service elements.

The Ontario government first dabbled in capitation in the 1970s through its Health Services Organization program. In 2002, physicians were allowed to adopt the Family Health Network model, also based on global payment. But it wasn't until the 2005 introduction of the Family Health Organization program - which covers more services and offers a higher capitation rate that Ontario doctors began switching in large numbers. This model became so popular, in fact, that the government at one point issued a temporary moratorium to slow down the massive wave of doctors making the transition.

"In 2002, doctors in Ontario were very skeptical. ... There was a lot of suspicion of government at the time, but then they realized that their incomes would go up and their workloads would maybe stabilize or go down. Of Ontario physicians who went into capitation, virtually none have gone back," says Dr. Richard Glazier, senior scientist with the Institute for Clinical Evaluative Sciences in Toronto, Ontario.

The Ontario government has put much effort into promoting capitation because expenses are very predictable in this payment model and because it allows for the creation of family health teams. Under a fee-for-service system, family physicians have little financial incentive to work as part of a team of health care providers. Sometimes, fee-for-service doctors perform duties they may be overqualified for - giving allergy shots, for example - because they would not be reimbursed if the task was performed by nurses. Such teams are seen as a way to maximize the effectiveness of family doctors, a scarce resource in Ontario.

"The family health team is a flagship initiative of this government," says Dr. Brian Hutchison, editor-in-chief of Healthcare Policy.
These teams not only relieve physicians of performing easier tasks, but also allow them to relay patients to health care professionals who are more qualified to offer certain services. A team could, for instance, include a pharmacist to assist patients with their medications and a psychiatrist to help them with mental health issues. Such a team could allow a practice to enrol more patients, and thus collect more capitation fees.

"From the patient's perspective, you go to one place and more of your needs are better met," says Dr. William Hogg, director of the C.T. Lamont Primary Health Care Research Centre in Ottawa, Ontario.

Proponents of capitation say it encourages high-quality care rather than maximizing throughput. In a feefor-service system, according to Hogg, there is a "perverse incentive" to bring patients back more than once for problems that could be addressed in one visit. On the other hand, fee-for-service does encourage doctors to work hard and see many patients.

To encourage doctors who switch to capitation systems to still see as many patients as before, the Ontario government pays them bonuses for meeting certain targets. These include getting a set percentage of their female patients in a certain age range to have mammograms 
and Pap smears. An added bonus of these incentives is that they encourage doctors to shift to electronic records to better track outcome measures. Physicians also receive bonuses if their patients don't go to other practices, which is another incentive to provide a high level of care.

Another advantage of fee-forservice that could be lost in a capitation system is transparency. The government could easily monitor all services provided by doctors under the old system because it was billed for each one. To keep this valuable information coming in, the government has created a "shadow billing system," which pays doctors $10 \%$ of traditional fees.

"If you are only paid by capitation, then there is no incentive to bill. If you are making $10 \%$ of the fee, then it is worth it," says Hogg. "Financial incentives do affect people's behaviour. That is true for physicians as well as anybody else."

Critics of capitation point out another potential negative of shifting from feefor-service: an incentive to enrol only the healthiest patients. In some countries, capitation fees are adjusted according to many factors, including socio-economic standing and health status. In Canada, they are currently adjusted only according to a patient's age and gender. That means doctors don't get paid more to care for sicker patients, who require more time and resources. This makes capitation a much less attractive option for doctors in urban centres than for those in wealthy suburbs, where patients tend to be healthier and need less care.

"Doctors in the inner city could be missing out in the order of $\$ 30000$ compared to those in small cities or rural areas," says Glazier.

Setting and adjusting capitation fees aren't the only complicated parts of implementing a global payment system.

It is difficult to create a system that works, with the right mix of incentives, but it is necessary if Canada is to improve its primary care system, says Hogg. "It's very complicated but it's better. It's not perfect yet, but it's already better than fee-for-service from the perspective of patients and doctors." - Roger Collier, CMAJ

\section{More news at cmaj.ca}

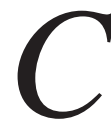

MAJ health news is now online daily as part of the journal's move to electronic publishing. The shift allows us to provide more stories to readers, on a more timely basis, while also publishing more Dispatches from the Medical Front. The following represents some of the pieces which have been posted at www.cmaj.ca since the last print edition of the journal.

Vaccine availability: Chief Public Health Officer of Canada Dr. David Butler-Jones can recommend the release of pandemic (H1N1) 2009 influenza vaccine before November if incidence or severity increases "or there's a great public health risk." - Laura Eggertson, Ottawa, Ont.

Limited progress: Former federal health minister Tony Clement established the Sodium Working Group in 2007, touting it as a "major step in helping Canadians improve their health," particularly in the reduction of cardiovascular diseases. Yet, two years later, little has emerged from the working group. - Becky Rynor, Ottawa, Ont.

Counterfeit drugs: China is known for producing fake Gucci sunglasses and iPhones, and is now earning a reputation for producing counterfeit medicines as well. - Katie Lewis, Beijing, China

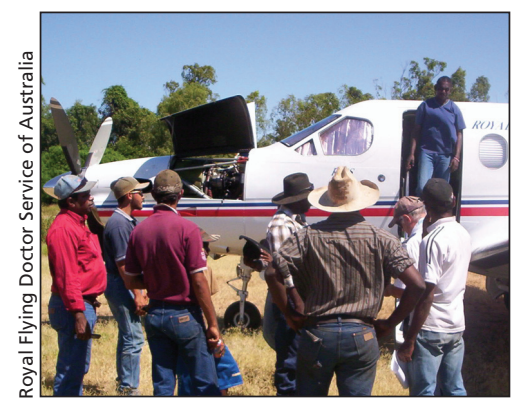

High-flyers: The fabled Royal Flying Doctor Service of Australia is providing an increasingly wider array of health services. - Ann Silversides, CMAJ

Correcting the course: The Canadian Institutes of Health Research propose to bolster clinical, population health and health services and systems research. - Wayne Kondro, CMAJ

Forget fee-for-service: Massachusetts is poised to become the first American state to shift its health care system from fee-for-service to capitation. - Roger Collier, CMAJ

\section{Dispatches}

Stark contrasts: Women in southern Sudan are almost 300 times more likely to die during pregnancy or childbirth than women in Canada. These statistics came to life vividly for an Ontario doctor during a trip to southern Sudan. - Lauralee Morris MD, Brampton, Ont.

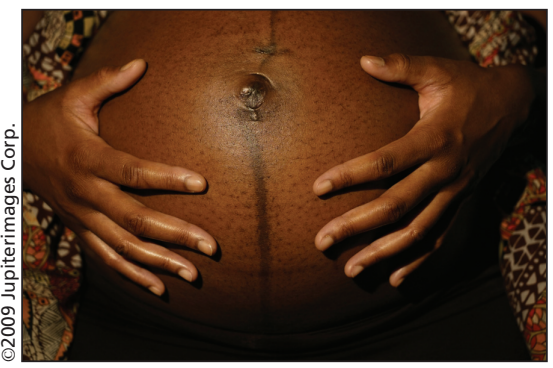

Minimedschool moments: A program to expose high school students to the joys and rigours of medical school has been well received in Vancouver, British Columbia. - Alasdair Nazerali-Maitland MBBS, London, UK

DOI:10.1503/cmaj.109-3076 